\title{
Entangled Narratives: How Literate Histories of Early Childhood Educators Expand Possibilities Within Online Learning Spaces
}

\author{
Kim Stewart and Candace Gallagher
}

\begin{abstract}
Kim Stewart has experience in the field of education as a teacher (both locally and internationally), principal, researcher, curriculum developer, subject coordinator, and instructor for the University of New Brunswick and St. Thomas University. Currently she is a PhD candidate in the UNB Faculty of Education and the coordinator for the bachelor of education in early childhood. Through the theoretical frameworks of new materialism, posthumanism, and critical feminism, Kim's research investigates ways to reconceptualize literacies and early childhood teaching/learning. Kim can be reached at stewart@unb.ca

Candace Gallagher is a PhD candidate in the Faculty of Education at the University of New Brunswick. She holds a bachelor of arts from St. Thomas University and a master of education from University of New Brunswick. Candace has experience teaching in early childhood settings, public school systems, and as an instructor at UNB. She has taught and has experience as a curriculum developer both internationally and locally. As a critical feminist researcher, she is investigating early childhood leadership as worldmaking through pedagogical documentation in the interest of social justice. Candace can be reached at candace.gallagher@unb.ca
\end{abstract}

Feminist ways of being allow us to be vulnerable and willing to admit doubt and to live expanded views of early childhood education and teaching. These practices are characterized by a love ethic, attending to entanglements of heartmindbody. In this article, we rely on entangled narratives between ourselves and early childhood educators asking how valuing entangled relationships can expand creative possibilities within online learning spaces. We draw from experiences within the newly established University of New Brunswick online bachelor of education in early childhood. Our research unfolds with a desire to value literate histories often silenced-sometimes lost-within standardized, institutional ways of being and becoming.

Key words: autobiographical narratives; feminist theory; love ethic; online learning

physics, we define our entanglement of women to be a relational obligation, bound to each other, moving forward, as cultivators of courage. Our entangled communities are built on a love ethic where early childhood educators "utilize all dimensions of love-care, commitment, trust, responsibility, respect, and knowledge" (hooks, 2000, p. 94). Detaching love from romance, critical Black feminist bell hooks (2000) theorizes love as a willful choice we make; hooks writes that "to begin thinking of love as an action rather than a feeling ... automatically assumes accountability and responsibility" (p. 13). Love is an action word. This accountability to others, "both in word and deed" (p. 92), and responsibility for the effects that result from our choices is an intersection where love and ethics begin to relate to one another (Endsley, 2016). Within our learning, we strive to courageously share our University of New Brunswick (UNB) online bachelor of education in early childhood education (BEd in ECE) degree program through autobiographical narratives (presented in italics), we ask how valuing the web of relationships expands affirmative and creative possibilities in online learning spaces. Our desire is to value the literate histories that are often silenced and sometimes lost within standardized, institutional ways of being and becoming. As critical feminist researchers, our goals for this article are to offer research that is hopeful to the field of early childhood education and to share entangled narratives that are "empowering to women" (Pillow, 2003, p. 178) who teach and learn with young children. Our combined 45 years of experience as early childhood educators informs us that women are responsible for most of the care and educating of young children in child care and the early years of schooling. As communities of early childhood educators, we are an entanglement of diverse women.

Thinking with the scholarship of Karen Barad (2012), researcher of feminist studies, philosophy, and particle

In this article, as we look to the beginnings of the 
stories, have difficult conversations, question ourselves and each other, and negotiate conflict as a valuable place for learning that engages the entanglements of the heartmindbody (Stewart, 2020). Connecting heart, mind, and body as entangled entities, we draw from and expand the concept of mindbody from Karin Murris (2016), scholar of pedagogy and philosophy, to include the word heart-heartmindbody.

\section{Institutional entanglements}

The selected narratives we share throughout this article focus on the lives of 12 women, all early childhood educators, who represent the first cohort of students to enroll in UNB's BEd in ECE online degree program. It is worth noting that UNB's BEd in ECE degree is a first of its kind in Canada, offering a BEd and a New Brunswick Certificate IV Teacher's Licence. Upon completion of the degree, early childhood educators will have the choice of working in early childhood centres and/or public school systems (kindergarten to grade 3). The choice of being an early childhood educator in schools represents a significant increase in wages, benefits, working conditions, resources budgets, and access to paid professional learning opportunities (Cannella, 2002; Moss, 2006; Osgood, 2004). These women have completed a two-year diploma in ECE from an accredited college and some have experience in early childhood centres as educators and/or directors, while others are educational assistants in the public school system. To apply for the BEd in ECE online degree program, the women provided a statement of interest and two letters of reference and completed the university application process, including an entrance interview.

As the coordinator of this program, I (Kim) have spent six months networking with early childhood educators via an email list generated during professional learning workshops over several years by the UNB Early Childhood Team. In New Brunswick (NB), it is a challenge to communicate directly with early childhood educators within the early childhood sector. While teachers in the public school system each have an individual work email, the NB government has not provided a listserv for early childhood centres and educators. Peter Moss (2010) speaks to these inequities, describing

the scandalous pay and working conditions and inadequate basic and continuing education of many "childcare workers"; the continuing split in many early childhood workforces between "childcare workers" and "teachers"; and the lower pay and status even of early years teachers compared with school teachers. (p. 8)

In spite of these systemic inequities, together, the UNB Early Childhood Team and early childhood educators applying for the program established a network of communicating, turning to texting, social media, and late night telephone conversations after their children were in bed.

Through autobiographical narratives like this one, we share the supportive entanglements between early childhood educators and members of the UNB Early Childhood Team in order to make visible the complexities of this online degree program. We carry within our heartmindbody an ethic of responsibility and care (Noddings, 2003), valuing the silent and complex narratives of these women as they speak to the intersectionalities of race, gender, and class - the narratives beyond their application forms, the marks on their transcripts, and the tidiness of their letters of reference and curriculum vitae. As educators, critical feminists, and vulnerable learners, we are prepared to lean over the edge (Jones, 2014) and dwell in the unpredictability of where their literate identities would lead them, and us, within this program.

We learned through the interview process that this cohort is a courageous group of diverse women who identify as mothers, daughters, wives, early childhood educators, directors of childcare centres, and/or educational assistants. During the interviews, these women shared their dreams of obtaining a university degree; in an effort to increase 
their qualifications, many had completed a diverse range of university courses, college programs, and locally developed professional learning opportunities. One story in particular that will never leave our heartmindbody is of an educator who used the janitor's closet to complete readings and assignments during her 45-minute lunch break. Backgrounds and prior experiences leave these women working against the current (Jones, 2014), veering away from the standardized pathways of completing a university degree. It has been shown that early childhood educators find themselves in the in-between spaces (Jones, 2014) of standardized, institutional education and providing essential but devalued care for Canada's youngest learners (Ballantyne et al., 2020; Berger, 2015; Khattar \& Callaghan, 2015; Moss, 2011).

In addition to these well-known complexities of the work of an early childhood educator, a global pandemic became a part of the entanglement of this community and program. The applicants' acceptance emails to the online degree program arrived in the midst of international, national, provincial, and local closures due to COVID-19. Their decision to enroll in UNB's online asynchronous degree program was made at a time when provinces were declaring states of emergency and quarantine measures were issued, leaving many without employmentincluding those who were employed as early childhood educators. During the global pandemic of 2020, this group of women decided to lean over the edge and begin their first courses less than two months into the pandemic. During complex and uncertain times, these women have shown their resilience and determination by seeking new possibilities despite unprecedented global events and ongoing systemic inequities.

\section{Entanglements of respectful relationships}

Hopes, apprehensions, concerns, insecurities, and messages of appreciation from early childhood educators flood my email and voicemail (see example Figure 1). These women felt that emailing and leaving a message on my phone was a space to voice the entanglements of their emotions related to themselves, their colleagues, and the sector of early childhood. They, like me, understand the opportunities and possibilities the degree offers to enhance the overall quality of early childhood education programs and pay inequities between early childhood educators and public school teachers.

\section{Thank you! We have so many talented ECE's leaving the field due to lack of recognition, salary, respect. I'll advocate for advancements to our field any day!!!}

Figure 1. Screenshot of email, April 2020.

An email from one of the early childhood educators arrived in my inbox: "Hey Kim, just a friendly reminder that Jan hasn't heard anything back about the program. Really if I was offered an interview, she should be too. Just checking, as I don't want her to miss this opportunity." It was this email that prompted me to revisit the admissions folder from the Office of the Registrar where I discovered Jan's application had not been included in the folder I received. After a number of telephone conversations with an admissions officer, Jan's application arrived in my inbox. It was stellar! At the eleventh hour and because of relational commitments, an additional time slot of 10:30 pm was added to the interview schedule, which Jan accepted. Her interview was emotional for members of our early childhood teamone that offered a glimpse into the life of a passionate single mother who desperately wanted to someday be an early childhood educator with a university degree.

This narrative reflects an ethic of love, one where communities of early childhood educators embody dimensions of love (hooks, 2002) in their everyday lives and relationships. In thinking about the online space we are striving to establish in this degree program, we are inspired by the ethic of care, relationality, and inclusivity we experienced 
when attending The Festival of Literary Diversity (FOLD) online in May 2020. The FOLD is Canada's first literary festival of diverse authors and storytellers. Their goal is to engage readers, inspire writers, and empower educators by highlighting often silenced voices (The Festival of Literary Diversity, 2020b). Similar to the goals of The FOLD, we hope to nurture a space for early childhood educators to experience love, mutual care, and respect in the online learning space of UNB's BEd in ECE. Therefore, we draw on The FOLD's definition of a safe space when creating our online learning community: "a space that prioritizes underrepresented and marginalized voices" (2020a, n.p.). We hope early childhood educators have the opportunity to lean over the edge with us and navigate the in-between spaces of early childhood, academia, and the public and private worlds of women (Grumet, 1988). These in-between spaces are important for this online degree program because of our desire, as instructors and coordinators, to enact an ethic of love, care, relationality, and inclusivity for these diverse women.

\section{Entanglements of respectful teaching}

As we text each other on a Tuesday morning about the first set of assignments submitted for Cultural Constructions of Childhood, a course Candace is teaching, we are reminded once again that as adults, we are always being and becoming: "literacy learning is part of [our] histories, not something that [we] do as a cognitive task divorced from [our] lives" (Hicks, 2002, p. 37). This is evident in the following narrative that shares an image of a text message between Kim and Candace (Figure 2).

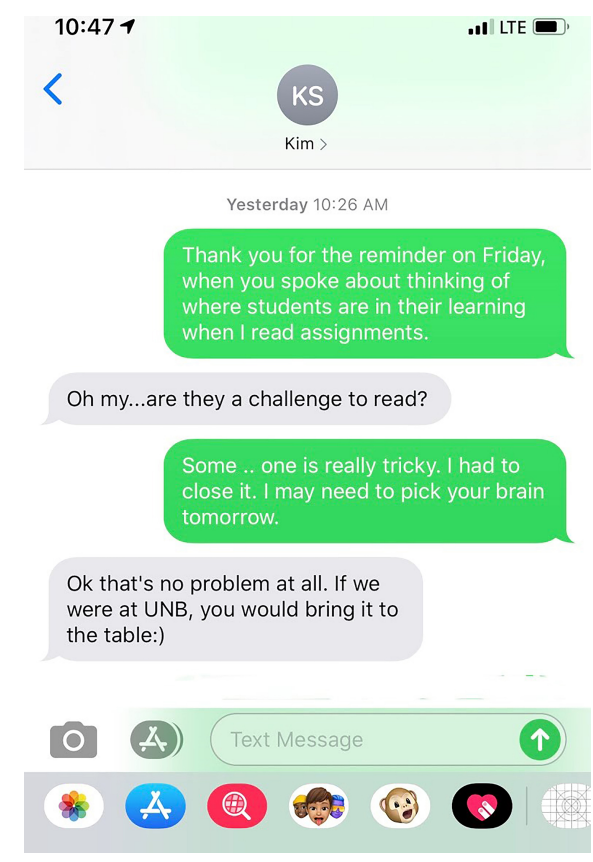

Figure 2. Screenshot of personal communication, June 3, 2020.

Files sit open on my laptop, the first collection of assignments submitted by the women in the BEd in ECE degree program, and I (Candace) stare at the white space smothering the letters, the blinking cursor, and the haze of words stare back at me. It's moments like this, I have to remember the layers of literate histories-it's about much more than what is written to fulfill the requirements of the assignment. "Who am I to assess their work?" "Am I an imposter within a place of privilege loaded with responsibility?" I sit here not only as an educator, but also a learner, learning with the women who have submitted these assignments. In these moments, Stephanie Jones (2014), a critical feminist literacy researcher who reflects on teaching in a community-based writing project, articulates my contradictory positioning: 
These shared moments of being together immersed in dialogic interactions, when our roles as student and teacher were blurred and we became ... people trying to make sense of one another and our work in the world, are what [we] have come to see as a key part of the "critical" work in complex teaching and learning. (p. 17)

In order to better understand myself as an instructor, my heartmindbody revisits the many conversations with UNB's Early Childhood Team. In preparation for the first cohort of educators, we have been imagining and negotiating the possibilities for this online learning space and continue to plan curricula and discuss community building. These layers of conversations and learning are the in-between spaces we embody as instructors. I wonder if this is the same space that these women, as students, are experiencing as they learn how to navigate the unfamiliar landscape of university, which is not necessarily part of their literate histories? Are my anxieties of "getting it right" as an instructor a jagged image of the early childhood educators' understanding and negotiating the academic code of university (S. Rose, personal communication, 2020)? My conversation with Kim prior to the text message (Figure 2) reminds me that we are at different places in our learning because of our class, gender, and race-our literate histories. Conversations like these happen as we meet digitally each week, sometimes more frequently, to critically analyze the worldmaking (Goodman, 1978) that is unfolding. Individual learning journeys follow their own path; our discussions are open and supportive, helping create opportunities and deepen knowledge and experiences as we question normative university assessment processes. Even our assessment philosophies are in conversation with their literate identities, building respectful and responsive relationships, and creating communities of reciprocity and equity.

\section{Conclusion}

As critical feminist researchers, we embrace the unpredictability that occurs when we continue to forge relationships which honour the literate identities of early childhood educators. It was our desire to share the beginnings of UNB's online BEd in ECE in this paper to make visible the entanglements of relationships when heartmindbodies come together in unfamiliar territories. As early childhood educators and university instructors cohabit this online space, new and unpredictable events continue to occur-events that encourage new ways of being and becoming. Moving together as cultivators of courage with an ethic of love, we lean over the edge in the in-between spaces, hoping to expand affirmative possibilities for the field of early childhood education.

\section{Acknowledgements}

We thank Vanessa Wintoneak, our critical friend, for becoming entangled with us and our writing. You challenged our thinking, provided thoughtful feedback, and encouraged us to pay attention to the details of our narratives. Thank you for seeing the possibilities within our writing. 


\section{References}

Ballantyne, M., Giesbrecht, D., Smith, C., Friendly, M., \& Greenwood, M. (2020, June 10). Round table 1: Moving forward with uncertainty: The pandemic as déclencheur* for a competent ECEC system across Canada. [webinar]. Sketching narratives of movement towards comprehensive and competence early childhood educational systems across Canada. https://www.youtube.com/ watch?v=PkgCpglV5Pg

Barad, K. (2012). On touching: The inhuman that therefore I am. differences, 23(3), 206-223. https://doi.org/10.1215/10407391-1892943

Berger, I. (2015). Pedagogical narrations and leadership in early childhood education as thinking in moments of not knowing. Journal of Childhood Studies, 40(1), 130-147. https://doi.org/10.18357/jcs.v40i1.15215

Cannella, G. S. (2002). Deconstructing early childhood education: Social justice \& revolution Peter Lang.

Endsley, C. L. (2016). The fifth element: Social justice pedagogy through spoken word poetry. SUNY Press.

Goodman, N. (1978). Ways of worldmaking. Hackett.

Grumet, M. (1988). Bitter milk: Women and teaching. University of Massachusetts Press.

Hicks, D. (2002). Reading lives: Working-class children and literacy learning. Teachers College Press.

hooks, b. (2000). All about love: New visions. Harper Collins.

Jones, S. (Ed). (2014). Writing and teaching to change the world: Connecting with our most vulnerable students. Teachers College Press.

Khattar, R., \& Callaghan, K. (2015). Beyond professionalism: Interrogating the idea and the ideals. Canadian Children, 40(1), 5-19. https://doi.org/10.18357/jcs.v40i1.15208

Moss, P. (2006). Structures, understandings and discourses: Possibilities for re-envisioning the early childhood worker. Contemporary Issues in Early Childhood, 7(1), 30-41. https://doi.org/10.2304\%2Fciec.2006.7.1.30

Moss, P. (2010). We cannot continue as we are: The educator is an education for survival. Contemporary Issues in Early Childhood, 11(1). https://doi.org/10.2304/ciec.2010.11.1.8

Moss, P. (2011, February 7). What is your image of the child? Critical questions in early childhood policy, provision, and practice. Public presentation, Fredericton, NB.

Murris, K. (2016). The posthuman child: Educational transformation through philosophy with picturebooks. Routledge.

Noddings, N. (2003). Caring: A feminine approach to ethics and moral education (2nd ed.). University of California Press.

Osgood, J. (2004). Time to get down to business?: The responses of early practitioners to entrepreneurial approaches to professionalism. Journal of Early Childhood Research, 2(1), 5-24. https://doi.org/10.1177/1476718X0421001

Pillow, W. S. (2003). Confession, catharsis, or cure: The use of reflexivity as methodological power in qualitative research. International Journal of Qualitative Studies in Education, 16(2), 175-196. https://doi.org/10.1080/0951839032000060635

Stewart, K. (2020). Sacred encounters: Literacy Beyond Cardboard Words. (Unpublished doctoral dissertation). University of New Brunswick, Fredericton, NB.

The Festival of Literary Diversity. (2020a, May 30). FOLD 2020: Fractured fairytales online panel. https:/www.youtube.com/ watch? $=08$ acwyOqBWM\&t $=1 \mathrm{~s}$

The Festival of Literary Diversity. (2020b). Home: The FOLD. https://thefoldcanada.org/ 